\section{Research Article}

(c) 2021 Jie et al.

This is an open access article licensed under the Creative Commons Attribution-NonCommercial 4.o International License (https://creativecommons.org/licenses/by-nc/4.o/)

\title{
Mitigating Academic Boredom and Increasing Well-Being Among Chinese College Students Based on a Positive Education Approach
}

\author{
Zheng Jie ${ }^{1}$ \\ Samsilah Roslan ${ }^{1, *}$ \\ Mohd.Mokhtar Muhamad \\ Mas Nida Md Khambari ${ }^{1}$ \\ Zeinab Zaremohzzabieh ${ }^{1}$ \\ ${ }^{1}$ Faculty of Educational Studies, Universiti Putra Malaysia, \\ Serdang, 4230o, Selangor, Malaysia \\ ${ }^{*}$ Corresponding Author
}

DOI: https://doi.org/10.36941/jesr-2021-0131

\section{Abstract}

Academic boredom is negatively related to students' academic outcomes like intrinsic motivation. Positive education is dedicated to improving both students' academic outcomes and wellbeing. In this study, China's " $6+2$ " positive education model was adopted to develop an intervention program that aimed to reduce academic boredom and improve positive emotions, thought-action repertoires, and intrinsic motivation. Theoretically, this emotion-oriented treatment is expected to cultivate positive emotions to broaden students' attention scope, widen their thought and action repertoires, facilitate intrinsic motivation and build up enduring psychological resources that help them better cope with negative emotions like academic boredom and trigger upward spirals toward emotional wellbeing. This proposed model fills a research gap in existing interventions and provides new theoretical knowledge in terms of reducing academic boredom and improving academic success as well as wellbeing among Chinese college students. The theoretical framework of this study consisted of the broaden-and-build theory of positive emotions, basic psychological needs theory, and the control-value theory of academic emotions.

Keywords: Positive education; Intervention; Academic boredom; College students; China

\section{Introduction}

Academic boredom is described as a negative and deactivating academic-related activity emotion (Pekrun et al., 2010) that is highly ubiquitous among college students (Mann \& Robinson, 2009). Studies showed that nearly 50\% of Chinese college students complained about being bored at some moment in class as compared to Canadian college students (26-41\%) (Tze,2011). Similarly, in a study by Tze et al. (2013), boredom while studying or in class was also obvious among Chinese undergraduate students. In addition, Sharp et al., (2016) revealed that college students in England 
usually adopted some behaviors against academic boredom, manifested in sleepiness, yawning, daydreaming, texting, and turning to social media in class.

The negative influence of academic boredom on students' learning and performance is longterm and multi-dimensional (e.g., Pekrun et al., 2010; Tze et al., 2014). In their 2010 study, Pekrun et al noted that university students' academic boredom was uniformly negatively related to intrinsic motivation across five studies using qualitative, cross-sectional, and predictive methodologies from different cultural contexts. In addition, Tze et al.'s (2016) meta-analysis of 29 studies covering 19052 students confirmed that there existed an overall negative relationship between academic boredom and academic outcomes (motivation, learning strategies, and performance), and the results also demonstrated that academic boredom had the greatest negative impact on students' intrinsic motivation and their use of learning strategies and the boredom-intrinsic motivation relationship was greater than boredom-academic relationship (Tze et al., 2016). In addition, this study also found that class-related boredom is more strongly negatively related to student learning process and achievement than learning-related boredom, which might be associated with a greater extent of shortage of perceived control in class than while studying. In short, academic boredom contributed negatively to students' academic learning outcomes, especially intrinsic motivation.

Since academic boredom is one of the common emotions in Chinese college students based on the empirical evidence and practical perspectives, it is of great importance for educators, researchers, and practitioners to scientifically identify and develop an effective intervention method to simultaneously foster the emotional wellbeing and academic performance of Chinese college students.

At present, only limited studies have been conducted pertaining to the interventions to address academic boredom. Most of the existing interventions for academic boredom adopted deficitoriented or therapy-based interventions such as systematic desensitization therapy, attributional retraining (AR) treatment, mindfulness training, life analytic group counselling based on the Satir's model, and emotional instruction method (Antonietta, 2008; Ijeoma \& Oladipo, 2019; Perry, 2014; Trunnell et al., 1996; Feng, 2017; Gao et al., 2018). Admittedly, each has proven effective in lowering academic boredom in general.

However, each of the interventions has some limitations. For example, the pathological approach that these deficit-oriented or therapy-based interventions can bring some outcomes. Specifically, those interventions were given to students who were assessed with more visible signs of academic boredom in the form of group counseling (Gao et al., 2018), which might make them feel being labeled as problematic, and might lead to a downward mental health spiral and subsequently bring other serious learning and mental health problems (O'Connell et al., 2009). Meanwhile, those who might not suffer from excessive academic boredom at that moment could be temporarily neglected and might become weak mentally when setbacks hit them in the future.

In addition, previous intervention programs only aimed to reduce academic boredom by focusing on symptom control. To the best of our knowledge, few studies have examined the effectiveness of interventions both on reducing academic boredom and increasing student wellbeing or positive constructs in China. Studies have showed that the absence of negative emotions do not necessarily mean the automatic increases in positive constructs such as positive emotions (Westerhof \& Keyes, 2010).That is, preventing or minimizing problematic negative emotions does not in itself foster positive emotions (Fredrickson, 200o). Thus, it may be helpful to consider shifting the "deficit-focused" educational model to "strength-based" approaches, which mainly emphasize positive experiences and traits like positive emotions, engagement, good relationship, meaning and achievements.

This could be achieved by using a positive education intervention that targets both at decreasing academic boredom and increasing positive emotions, thought-action repertoires and intrinsic motivation in China. Positive education has three aspects: pursuing both well-being and academic success; using scientific measurements to assess the levels of well-being, the alleviation of ill-being, and the academic performance before and after; using well-validated interventions that increase well-being and decrease ill-being (Seligman \& Adler, 2019). Four published meta-analyses 
confirmed positive education was effective in reducing negative emotions such as depression, anxiety, and stress and increasing psychological well-being (Bolier et al., 2013; Alan et al., 2020; Hendriks et al., 2020; Sin \& Lyubomirsky, 2009). In addition, various positive education programs showed empirical evidence for the effects of improving students' academic performance (Adler,2016; Norrish et al., 2013; Waters, 2011; Zeng et al.,2019).

Thus, the tailored positive education intervention program based on China's positive education model "6+2" (SPERMA) works through cultivating students' Positive Self-concept, Positive emotions, Engagement, Relationships, Meaning, and Achievements to both alleviate academic boredom and improve positive emotions, thought-action repertoires, and intrinsic motivation among Chinese college students.

\section{Theoretical Framework for This Study}

The theoretical framework of this study drew from the broaden-and-build theory (Fredrickson, 2001), the control-valued theory (Pekrun et al., 2010; Pekrun et al., 2006), and the three basic psychological needs theory from self-determination theory (Ryan \& Deci,2002;2000). Here is a brief description of each theory and its relations.

First, the positive education approach refers to the application of positive psychology theory and interventions to educational settings to increase both academic success and student well-being (Seligman et al.,2009). In the positive psychology field, an individual's well-being consists of five components: positive emotions, engagement, positive relationships, meaning, and accomplishment (PERMA; Seligman, 2011). One meta-analysis study confirmed that multi-component positive psychological interventions (MPPIs) like PERMA are both effective in promoting people's wellbeing and decreasing their negative emotions such as depression, anxiety, and stress (Hendriks et al., 2020). A review of school-based positive psychology interventions showed that wellbeing is a protective factor against youth depression and facilitates creativity (Waters, 2011).

As per the control-value theory (CVT) of academic emotions, on the one hand, boredom is a negative and deactivating academic-related activity emotion while control and value are two proximal antecedents of inducing boredom (Pekrun et al., 2010); boredom narrows an individual's thought-action repertoires (Pekrun et al., 2014; Fredrickson, 1998; Fredrickson \& Branigan, 2005), and in turn affects attention and intrinsic motivation as well as subsequent academic performance. On the other hand, the CVT posits that different regulatory approaches including appraisal-focused, emotion-oriented, and problem-solving ones could manage this negative emotion (Pekrun, 2006). Positive education is an emotional-oriented regulatory approach.

Second, according to the broaden-and-build theory of positive emotions (Fredrickson, 20o1; Fredrickson \& Branigan, 2005), positive emotions can reduce negative emotions and facilitate intrinsic motivation, which allows people to notice things they would not otherwise notice. Positive emotions broaden people's attention, widen momentary thought-action repertoires, undo negative emotions by increasing people's attention to a broader scope (Fredrickson, 200o) and facilitate people's creative thinking (Isen et al.,1987; Estrada et al., 1994). It can boost students' readiness to try new activities, promote intrinsic motivation and make students feel more engaged in academic activities. Moveover, it can accumulate their enduring psychological resilience and set up upward spirals of emotional wellbeing that lead to fewer negative emotions. Pekrun et al. (2002) demonstrated that the relationships between students' positive emotions and their motivation to learn.

Third, in accordance with the three basic psychological needs theory from self-determination theory (SDT) (Ryan \& Deci,2002;2000), human beings have three basic psychological needs, namely autonomy, competence, and relatedness, and all of which are associated with the facilitation of intrinsic motivation and well-being. Tze et al' s (2014) study showed that there was a negative relationship between perceived autonomy support and boredom in class. Empirical findings from the first positive education curriculum confirmed that positive education programs could improve students' academic performance (Seligman et al., 2009), which may attribute to both positive 
education content and activity teaching methods they used, including class discussions, in-class activities, a real-world homework activity, and reflective journals. Previous studies have showed that activity teaching patterns can reduce academic boredom and increase positive emotions (Zhao et al., 2012; Ma et al., 2010), which indicated that activity teaching patterns satisfied students' three basic psychological needs and made them more willing to engage in the current activities or tasks.

In the above discussions, the broaden-and-build theory is the main theory of this intervention study, which assumes that fostering positive emotions can broaden people's momentary thoughtaction repertoires, undo negative emotions, fuel psychological resilience, creativity, facilitate intrinsic motivation, and trigger upward spirals of emotional wellbeing that lead to fewer negative emotions. Thus, the theoretical framework is illustrated below:

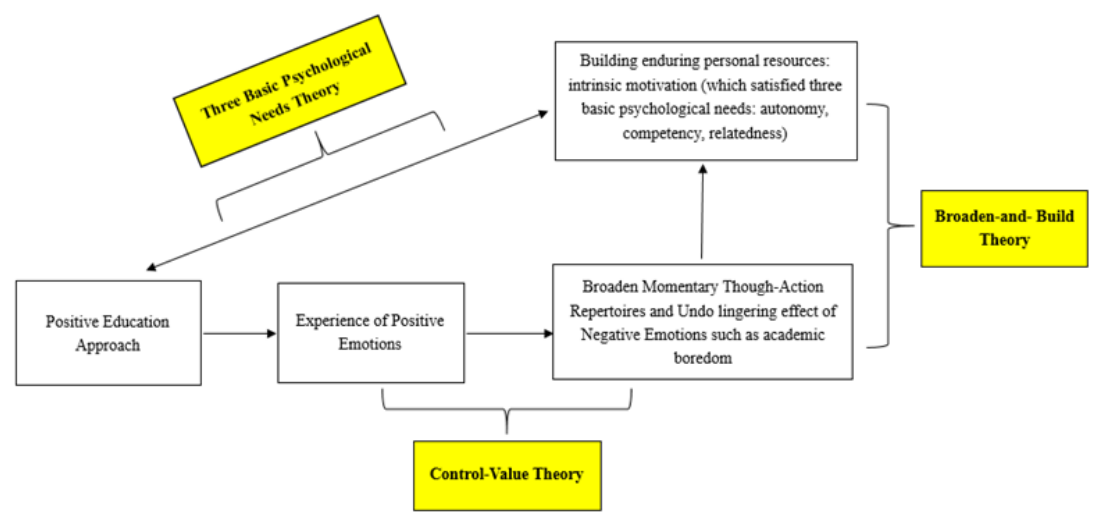

\section{The Positive Education Intervention Program}

\subsection{Intervention model: China's " $6+2$ " positive education model}

In this study, the researcher adopted China's " $6+2$ " positive education model (Zeng et al.,2019) and developed 13 weekly sessions of positive education content (90 min per week). The positive education intervention program includes an introductory session and six main modules: positive relationships, positive emotions, positive self, positive engagement, and positive achievements. The researcher mainly used positive activities and practical skills to foster students' positive emotions.

China's " $6+2$ " positive education model was developed by Tsinghua University. It is a local positive education model that sums up the experience of positive education practice in China (Zeng et al., 2019). This model refers to Martin Seligman's PERMA model of well-being (positive emotions, engagement, positive relationships, meaning, and achievement) (Seligman, 2011) and draws lessons from other successful positive education practice systems in the world such as Geelong Grammar School's model for positive education that consists of six wellbeing domains (Norrish et al., 2013), and TecMilenio university's ecosystem of wellbeing and happiness (Seldon \& Martin, 2017). Finally, they devised a new Chinese positive education model that comprises of six modules and two systems: the "6+2" model (Zeng et al., 2019).

\subsubsection{Positive self-concept-building self-confidence with one's strengths}

Positive self-concept is a product of localizing positive education in China. As noted by Tsinghua University researchers that implemented positive education in China, self-confidence, self-esteem, self-love, self-awareness, and self-acceptance are underappreciated and relevant content is rarely taught in Chinese classes (Zeng et al.2019). Therefore, adding a positive self-concept to the practice 
model can help improve the training effect of other modules.

The module of positive self-concept is dedicated to helping students to develop a positive selfconcept so that they can have stable self-esteem, sufficient self-efficacy, and lasting self-love (Zeng \& Zhao, 2019). Related supporting theories are self-esteem and self-efficacy (Judge et al., 1998).

\subsubsection{Positive emotions - improving positive emotions and managing negative emotions}

The module of positive emotions focuses on improving students' ability to identify and manage their emotions and teaching students to master the basic laws of emotions, to trigger and enhance positive emotions, and regulate and cope with negative emotions (Zeng et al.,2019). The main related supporting theory is the broaden-and-build theory of positive emotions (Fredrickson, 1998, 2001).

\subsubsection{Positive engagement-experiencing flow and enhancing intrinsic motivation}

The module of positive engagement is aimed at inspiring students' intrinsic motivation to live and to learn, to develop deeper concentration and engagement so that they can learn to actively achieve a flow state, be dedicated and fall in love with their study, and find happiness therein (Zeng et al.,2019). The main related supporting theory is flow theory (Csikszentmihalyi, 1990).

\subsubsection{Positive relationships_cultivating empathy and learning positive interpersonal communication}

The positive relationship module aims to develop students' ability to establish positive interpersonal relationships and learn positive and effective communication skills, such as active and constructive responses so that they can build a positive, stable, and mutually supportive interpersonal relationship (Zeng et al.,2019). The main related supporting theory is active constructive responding (Gable \& Reis, 2010).

\subsubsection{Positive meaning - establishing growth values and stimulating inner driver to achieve goals}

Positive meaning aims to help students cultivate growth values, create a sense of meaning and direction in life, pursue valuable and meaningful life goals (Zeng et al.,2019). The related supporting theory is the theory of meaning (Stillman \& Baumeister, 2009; Martela \& Steger.2016).

3.1.6 Positive achievement-boosting willpower and growth mindsets, laying a foundation for future achievements

Positive achievement aims to cultivate students' resilience after setbacks, perseverance, problemsolving skills, and growth mindsets to improve their ability to achieve valuable goals (Zeng et al.,2019). The main related supporting theory is the theory of growth mindsets (Dweck, 2016).

\subsubsection{Two systems: Physical and mental health regulation system-meditation and relaxation training}

Positive education is committed to using scientific intervention techniques to cultivate students' continuous and effective behavior habits and skills to maintain their physical and mental health (Zeng et al.,2019). The related supporting theory is the holistic health theory (Hassed, 2008).

\subsubsection{The cultivation system of character strengths-6 virtues and 24 character strengths}

Character strengths and virtues are the cornerstones of positive education, which can be defined as positive traits reflected in thoughts, feelings, and behaviors (Park et al., 2004). Peterson and Seligman, founders of positive psychology, have studied the mainstream values and cultural heritage 
of various ethnic groups, including Confucianism, Buddhism, and Taoism in China, and found six virtues and twenty-four character strengths of human beings (Peterson \& Seligman,2004). From a strengths perspective, everyone has unique strengths that can help them to achieve well-being and perform well (Wood et al., 2011). China's positive education model " $6+2$ " organically integrates these 24 character strengths into the 6 modules, with the purpose of educating students through entertainment and exerting a subtle influence (Zeng et al.,2019).

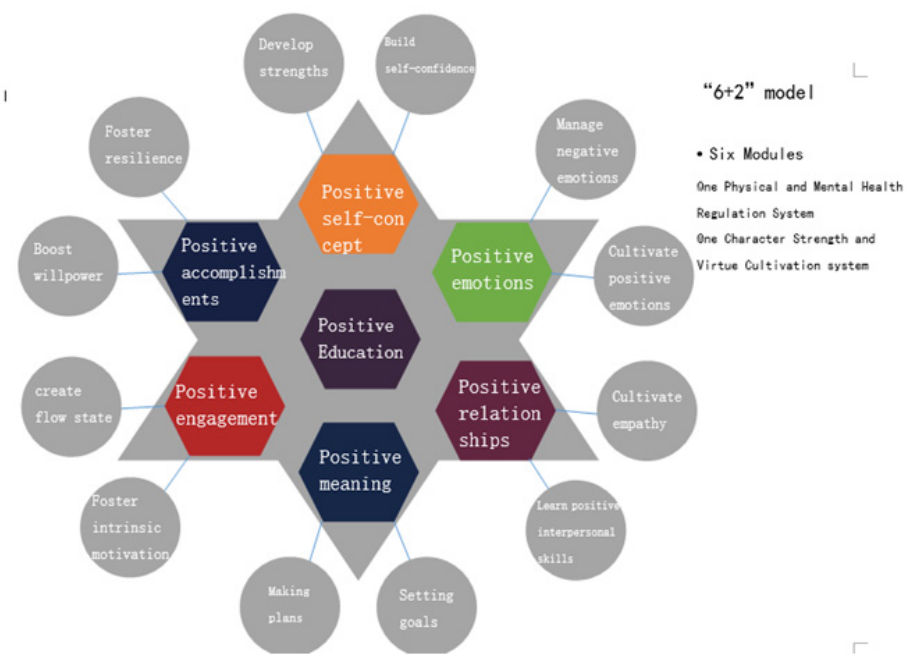

In the past five years, this positive education $6+2$ model has been applied in different levels of educational settings, including 7 primary schools, 4 middle schools, 1 technical secondary school and 1 university (Zeng et al.,2019). For example, they did an experimental study in Yuncheng Vocational School from 2016 to 2017. Their findings showed that the experimental group had increased scores in psychological resilience, growth mindset, and hope as compared to the control group (Global Happiness Council, 2019).

\subsection{The overall framework of the intervention program}

Overall, each session covers four stages: the meditation practice stage, the positive cognition stage, the skills training stage, and the practice enhancement stage. The entire teaching process is carried out in an incremental, upward spiral.

The researcher began each session with a meditation practice, which lasted 5 min before the formal class. The purpose of doing this was to help students become more mindful and engaged in the program. A previous study suggested that after practicing 20 minutes of mindfulness meditation can help Chinese undergraduates became more alert and conscious as compared to the control group (Ren et al., 2011).

In the stage of positive cognition, interesting scientific videos, on the one hand, were used to trigger positive emotions and on the one hand, to form a preliminary understanding of the six aspects to be intervened, stimulate curiosity, and increase the desire to explore, on the other hand.

In the skills training stage, intervention techniques that have been proven effective in increasing psychological wellbeing were adopted to further improve students' skill levels in these six aspects, to bring about positive emotions. The researcher mainly used hands-on positive activities such as paper and pencil tasks, group discussions, hands-on activities, storytelling, and free sharing, as well as practical skills that students could use in their daily routine. Both elements aimed to generate longlasting effects. Each session had 2 group activities, which were designed to meet their needs for autonomy, relatedness, and competency. 
In the practice enhancement stage, targeted after-class activities were designed mainly around these six aspects. On the one hand, the researcher provided timely feedback, strengthened experience of positive emotions, and taught activity design principles and intentions. On the other hand, the researcher emphasized the importance of after-class practice, assigned targeted assignments, and wrote reviews before starting the next class to evaluate students' practical learning situations. There were 2 after-school activities in each session, and students were asked to complete one of them. This gave students more autonomy to tap into their intrinsic motivation and encouraged them to take positive action. In this way, students could feel better about themselves mentally and physically, thereby accumulating more positive resources. In addition, afterschool assignments helped the researchers find out how interventions produced changes and identify whether each aspect of this process occurred as expected.

Horizontally, each module transited from the positive cognition stage to the effective skills training stage, and then to the practice enhancement stage. The purpose was to make the teaching and learning process no longer boring and meaningless. Further, it aimed to stimulate positive emotions in students, spark their intrinsic motivation to learn, make them engaged in hands-on activities, and gradually improve their positive emotions through practicing corresponding skills. Vertically, each session had clear goals, timely feedback, and appropriate difficulty, which could encourage students to involve themselves in learning and experience more positive emotions. In short, it is necessary to make students not only feel good in class but also act well in their daily life.

The positive education program was mainly carried out in form of group activities, group discussions, and real-world homework, supplemented by theoretical instruction. Each session lasted 90 minutes 13 weeks for a total of 13 sessions.

The positive education intervention program mainly refers to "Positive Education in Action Featured Course Plans Grade 4-6" (Peng et al.,2019), "The Science of Well-being: The Application of Positive Psychology in Education" (Zeng, et al.,2019) and "Positive Psychology Group Activity Guide" (Yang et al.,2016), among others. Here is a brief outline of each session including topics, main activities and afterschool assignments:

\subsubsection{Introducing mindfulness (1 lesson) and cultivating positive relationships (2 lessons)}

In this kickoff session, we introduce the overall framework of this program and teach students how to do meditation.

To cultivate positive relationships, attachment theory is used to guide students to understand the sources and features of their interpersonal relationship patterns, to know the benefits of positive relationships, to train students to use empathy and active constructive responding to enhance and improve the quality of interpersonal relationships and to experience more positive emotions actively.

Table 1: Outlines the information about the introduction and positive relationships sessions

\begin{tabular}{|c|c|c|}
\hline Module & Subject & Content \\
\hline Introduction & Meditation & $\begin{array}{l}\text { 1. Introduce the overall framework of the course (help students discover inner strengths } \\
\text { scientifically, gradually get rid of the feelings of hopelessness in study and life, and } \\
\text { maintain long term happiness) and guide to enter the topic of mediation (watch the } \\
\text { video: Why mindfulness is a superpower). } \\
\text { 2. Learn abdominal breathing within three steps (watch the video clip: Meditation 101- A } \\
\text { Beginner's Guide) and do group activity: practice with group members. } \\
\text { 3. Do the meditation practice following the audio file "three-minute breathing space"; } \\
\text { Group activity: Drawing what I feel, to realize the benefits of doing meditation. } \\
\text { 4.Summarize the course and assign practice tasks (two tasks are given and students can } \\
\text { choose one of them: (1) Do the breathing meditation practice following the given audio } \\
\text { material every day. Then record your mood and feelings after it. Write down in } 200 \text { words; } \\
\text { (2) Find soft music that you like and record audio personally by using the given } \\
\text { instructions. Then practice it every day and record your mood and feelings after it. Write } \\
\text { 2oo words. }\end{array}$ \\
\hline
\end{tabular}




\begin{tabular}{|c|c|c|}
\hline Module & Subject & Content \\
\hline \multirow[t]{2}{*}{$\begin{array}{l}\text { Positive } \\
\text { Relationships }\end{array}$} & $\begin{array}{l}\text { Understand your } \\
\text { interpersonal } \\
\text { relationship } \\
\text { pattern }\end{array}$ & $\begin{array}{l}\text { 1.Review after-school exercise and introduce the relationship topic (Encourage students } \\
\text { to build a daily meditation practice habit and do the adult attachment patterns class quiz } \\
\text { to entry class topic) } \\
\text { 2.Learn the origin of interpersonal relationships (watch the video: introduce attachment } \\
\text { theory); group discussion; the teacher summarizes three different attachment styles and } \\
\text { their corresponding features. } \\
\text { 3.Learn the benefits of positive relationships (watch TED: what makes a good life? } \\
\text { Introduce the findings of the longest adult development study) and do the group activity: } \\
\text { storytelling. experience feelings of connecting) } \\
\text { 4.Course summary and assignment of practice exercises: } 1 \text { ) anxious style: find finding from } \\
\text { the people around you or WeChat Moments (Chinese popular social media app) a friend } \\
\text { who you think has a secure attachment style, and have a conversation with him/her for at } \\
\text { least } 15 \text { minutes, regardless of the topic. Write down the process of the activity and your } \\
\text { feelings in 2oo words; 2) avoidant style: the practice of self-disclosure: Step 1: find someone } \\
\text { important to you around you or from mobile phone Address Book/WeChat Moments and } \\
\text { start exercising; Step 2: share with him/her one thing that made you happy last week but } \\
\text { made you feel embarrassed to talk about. Write down the process of the activity and your } \\
\text { feelings within } 200 \text { words. }\end{array}$ \\
\hline & \begin{tabular}{|l|} 
Empathy and \\
active constructive \\
responding
\end{tabular} & $\begin{array}{l}\text { 1. Review after-school exercise and introduce the topic of empathy (highlight the } \\
\text { changeability of insecure attachment styles); guide students to think about empathy } \\
\text { emotionally (watch the video: Bao); questions and summary) } \\
\text { 2.Learn empathy (watch the video: the power of empathy; summarize three critical steps } \\
\text { to express empathy; group activity: interpersonal conflict moment, encourage students to } \\
\text { practice empathic skills) } \\
\text { 3.Learn active constructive responding (watch the video: introduce ACR; summarize how } \\
\text { to express using ACR); group activity: practice ACR when someone tells you a good } \\
\text { thing(attached); teacher summary, enhance students' sense of self-confidence. } \\
\text { 4.Course summary and assignment of practice exercises (1) When someone tells you good } \\
\text { news next week, consciously respond in an active way. If you haven't noticed anyone telling } \\
\text { you a piece of good news, actively ask them to share something good. Write down your } \\
\text { experience in } 200 \text { words; (2) chat with a friend, listen to him/her, express empathy, and } \\
\text { strengthen the emotional bond between each other. Write down the activity process and } \\
\text { your feelings in } 200 \text { words. }\end{array}$ \\
\hline
\end{tabular}

\subsubsection{Cultivating positive emotions (2 lessons)}

The cultivation of positive emotions consists mainly of three aspects: understanding emotions, cultivating positive emotions and managing negative emotions. Corresponding skills training activities are designed. Scientific skills and methods are used to foster students' positive emotions experience, relieve the impact of negative emotions, and build more positive resources.

\section{Table 2: Outlines the information about positive emotions sessions}

\begin{tabular}{|l|l|l|}
\hline Module & Subject & Content \\
\hline emotions & $\begin{array}{l}\text { eliminate the } \\
\text { misunderstanding of } \\
\text { positive emotions }\end{array}$ & $\begin{array}{l}\text { l.Review after-school exercise and introduce the basic emotions (focus on students' } \\
\text { feelings after practicing ACR and empathy skills and get into the topic of emotions; } \\
\text { watch the video clip: Inside out to guide students to know basic human emotions and } \\
\text { their functions, respectively) } \\
\text { 2.Recognize positive emotions (introduce 1o common positive emotion trigger } \\
\text { conditions and action tendencies); group activity: my positive emotions cake (attached), } \\
\text { to identify and share positive emotions that happened to oneself; teacher summary. } \\
\text { 3.Experience the benefits of positive emotions (watch the video clip: zootopia and do one } \\
\text { challenging task, manifesting that positive emotion can improve people's creativity), } \\
\text { learn how to cultivate positive emotions; group activity: show the beauty(attached), savor } \\
\text { good things can improve people's positive emotions. } \\
\text { 4. Course summary and practice exercise: (1) The Three Good Things: Starting today, every } \\
\text { night before you go to bed, write down three good things that happened to you during the } \\
\text { day and why they happened. Write down your feeling in 2oo words. (2) Find the one you } \\
\text { want most from the 1o positive emotions, actively create conditions to trigger that emotion } \\
\text { and experience the emotion carefully. Record the creation and experience process in } 200 \\
\text { words. }\end{array}$ \\
\hline
\end{tabular}




\begin{tabular}{|l|l|l|}
\hline Module & Subject & Content \\
\hline & $\begin{array}{l}\text { Manage Negative } \\
\text { Emotions }\end{array}$ & $\begin{array}{l}\text { 1.Review the Three Good Things exercise and strengthen their experiences of positive } \\
\text { emotions, and provoke thinking about the meaning of negative emotions. } \\
\text { 2.Group activity: inventory of negative emotions. To guide students to perceive their } \\
\text { negative emotions, learn to name them, and understand common negative emotions; } \\
\text { watch the video: amygdala hijack, learn the brain mechanism of negative emotions } \\
\text { 3.Group activity: be kind to negative emotions. To learn and practice the three-step } \\
\text { (identify, accept, express) method of dealing with negative emotions and practice. } \\
\text { 4.Course summary and exercise. (1) Help others unexpectedly: In the next week, when you } \\
\text { feel stuck in negative emotions, help/thank someone unexpectedly. Write down your } \\
\text { thoughts and feelings in 2oo words. (2) To be the master of your emotions: When you feel } \\
\text { stuck in negative emotions, adjust it according to the three-step method of knowing- } \\
\text { accepting-expressing. Think about what made you have such negative emotions, and how } \\
\text { you coped with them. Write down your thoughts and feelings in 2oo words. }\end{array}$ \\
\hline
\end{tabular}

\subsubsection{Cultivating positive self-concept (2 lessons)}

There are two ways to cultivate a positive self-concept. One is to accumulate successful experience and enhance self-confidence by identifying and discovering students' character strengths. The other is to further accumulate successful experience, improve self-esteem, strengthen positive selfconcepts, and feel more positive emotions by learning how to use strengths in disadvantaged situations and overcome difficulties and challenges.

Table 3: Outlines the information about positive self-concept sessions

\begin{tabular}{|c|c|c|}
\hline Module & Subject & Content \\
\hline \multirow[t]{2}{*}{$\begin{array}{l}\text { Positive } \\
\text { Self- } \\
\text { Concept }\end{array}$} & $\begin{array}{l}\text { Discover } \\
\text { Character } \\
\text { Strengths }\end{array}$ & $\begin{array}{l}\text { 1. Review after-school homework practice and introduce the topic of positive self (underscore to } \\
\text { use scientific methods to deal with negative emotions; Watch the video: you are more beautiful } \\
\text { than you think, guide students to think about how to know themselves comprehensively and } \\
\text { positively) } \\
\text { 2. Group activity: My joy. Discover students' character strengths based on your own experience, } \\
\text { enhance self-confidence, strengthen positive emotions, and consolidate positive behaviors. } \\
\text { 3. Group activity: Super Hat. To discover students' strengths with the help of others, expand } \\
\text { self-awareness, enhance self-confidence, heighten the positive experience, and optimize } \\
\text { interpersonal relationships. } \\
\text { 4.Course summary and assignment of practice exercises. Compulsory exercise: Log in a } \\
\text { designated website, take the character strength test to help you know your character strengths } \\
\text { from a scientific viewpoint. (1) Find your Blind Spot strengths within two steps, write down your } \\
\text { feeling in } 200 \text { words; (2) Introduce others 'signature strengths, write down your feeling in } 200 \\
\text { words. }\end{array}$ \\
\hline & $\begin{array}{l}\text { Develop your } \\
\text { strengths and } \\
\text { improve self- } \\
\text { confidence }\end{array}$ & $\begin{array}{l}\text { 1. Review after-school homework practice and find the signature strengths (Through getting } \\
\text { feedback from others, people can more confirm their significant strengths and more } \\
\text { importantly find out potential strengths; Watch the video: A moving story about gratitude, to } \\
\text { show how to practice strengths in daily life) } \\
\text { 2. Group activity: to stimulate your potential strengths. Help students find more ways to practice } \\
\text { their character strengths. } \\
\text { 3. Group activity: transfer of strengths. To use strengths to deal with disadvantaged scenarios, } \\
\text { enhance self-confidence and improve self-esteem } \\
\text { 4. Couse summary and assignment of practice exercises. (1) In the next week, try to complete the } \\
\text { items on the potential strength action card within one week to develop your potential strength. } \\
\text { After writing, take photos and write down the activity process and feelings within } 200 \text { words. (2) } \\
\text { According to your significant strengths, come up with at least } 5 \text { ways to practice after class and } \\
\text { complete them within a week. After writing, take photos and write down the activity process and } \\
\text { feelings within } 200 \text { words. }\end{array}$ \\
\hline
\end{tabular}

\subsubsection{Cultivating positive engagement ( 2 lessons)}

To cultivate positive engagement, on the one hand, design corresponding group activities in accordance with the conditions necessary to enter the flow state, and guide students to experience flow, spark intrinsic motivation and generate positive emotions. On the other hand, guide students to 
use the three conditions to generate flow (clear goals, immediate feedback, and the match between task difficulty and skill level), focus on teaching the SMART principle of goal setting, redesign boring situations, and actively create flow experience, thereby improving learning efficiency, reducing negative emotions, and increasing positive emotions.

Table 4: Outlines the information about positive engagement sessions

\begin{tabular}{|c|c|c|}
\hline Module & Subject & Content \\
\hline \multirow[t]{2}{*}{$\begin{array}{l}\text { Positive } \\
\text { Engagement }\end{array}$} & $\begin{array}{l}\text { Experience } \\
\text { flow }\end{array}$ & $\begin{array}{l}\text { 1. Review after-school exercise and introduce the flow topic (Highlight the importance of } \\
\text { practicing signature strengths in different ways and connect to flow topic; Watch a video: the } \\
\text { monkey business illusion, guide students to experience flow state) } \\
\text { 2. Group activity: the moments of flow: To connect the experience of flow to daily life and } \\
\text { learning, and further understand what "flow" is and what "the benefits of flow" are. } \\
\text { 3. Group activity: juggling balls: To guide students to experience flow in this activity, and } \\
\text { summarize the conditions needed to lead to a state of flow. } \\
\text { 4.Course summary and assignment of practice exercises: (1) Please find a small activity that easily } \\
\text { stimulates flow. Practice many times in this week, record the feelings that this activity brings you, } \\
\text { and find out the three conditions that produce flow in this activity. Write down in } 200 \text { words. (2) } \\
\text { Please find a friend, teach him/her the skill of three-ball juggling with both hands, and complete the } \\
\text { task of tossing and catching the ball for lo seconds within a time limit of } 20 \text { minutes. Interview the } \\
\text { friend whether he/she has experienced flow (focus, devotion, forgetting about the self), and ask why } \\
\text { this activity makes him/her happy (three conditions to create flow), write down in } 200 \text { words. }\end{array}$ \\
\hline & \begin{tabular}{|l|}
$\begin{array}{l}\text { Create a flow } \\
\text { experience }\end{array}$ \\
\end{tabular} & $\begin{array}{l}\text { 1.Review after-school exercise and introduce the topic of this section (highlight the feeling of } \\
\text { flow and summarize the three conditions to create flow; Watch the video: Achieve more by } \\
\text { setting smart goals; Questions and summary) } \\
\text { 2.Group activity: set a good goal with the SMART framework. To teach students the definition of } \\
\text { SMART and guide them to use it by setting a short-term goal. } \\
\text { 3.Group activity: Create a "micro flow" activity: To guide students to create activities involving } \\
\text { skills and challenges in some boring activities, and actively create a flow experience. } \\
\text { 4.Course summary and assignment of practice exercises. Please design a goal plan for your } 28 \text { - } \\
\text { day growth journey and start to implement it. The specific requirements are: (1) The goal is } \\
\text { meaningful to you, meets your inner needs, and is challenging. You need to persist in doing it } \\
\text { every day. The final result will bring you growth, rather than mere happy feelings;(2) Break down } \\
\text { the goal into small goals in different phases. They should be clear, specific, and actionable;(3) } \\
\text { There should be feedback promptly at each stage: self-feedback and feedback from others;(4) The } \\
\text { difficulty of each stage matches your ability better;(5) Find a friend or family member to join you } \\
\text { in the } 28 \text {-day growth journey and understand their goals;(6) Design a 28-day goal progress card as } \\
\text { a means of self-monitoring and complete the record each day. }\end{array}$ \\
\hline
\end{tabular}

\subsubsection{Cultivating positive accomplishment (2 lessons)}

To cultivate positive accomplishment, on the one hand, guide students to realize the importance of willpower to achieving goals and its characteristics as well as teach students know how they deplete their willpower and then summarize ways to increase willpower. On the other hand, teach students to use a growth mindsets and optimistic explanatory style to face obstacles and challenges that prevent them from achieving their goals.

Table 5: Outlines the information about positive accomplishment sessions

\begin{tabular}{|c|c|c|}
\hline Module & Subject & Content \\
\hline $\begin{array}{l}\text { Positive } \\
\text { Accomplishment }\end{array}$ & Increase willpower & $\begin{array}{l}\text { 1.Review after-school exercise and introduce the new topic (Share goals of a } \\
\text { friend or family member and check how many students complete the goal } \\
\text { every day and pay more attention to others who didn't finish their goals and } \\
\text { guide the willpower topic) } \\
\text { 2.Introducte to willpower and ways to use willpower effectively (Watch the } \\
\text { video: how willpower works; summarize characteristics of willpower; Group } \\
\text { activity: my willpower journal; Teacher summary) } \\
\text { 3. Group activity: "Start from } 5 \text { minutes" practice: To use micro-habits to } \\
\text { reduce willpower depletion and help students achieve their goals } \\
\text { 4.Course summary and assignment of exercises (Combined with today's } \\
\text { lesson and the willpower saving strategy, promote the achievement of daily } \\
\text { goals and keep a record of goal completion) }\end{array}$ \\
\hline
\end{tabular}




\begin{tabular}{|l|l|l|}
\hline Module & Subject & Content \\
\hline & $\begin{array}{l}\text { Develop a growth } \\
\text { mindset and an } \\
\text { optimistic explanatory } \\
\text { style }\end{array}$ & $\begin{array}{l}\text { 1.Second feedback of "28-day growth journey goal plan" (share homework } \\
\text { completion; Watch the video: Neuroplasticity, introducing the working } \\
\text { principle of neuroplasticity, emphasize the importance of hard work and } \\
\text { practice.) } \\
\text { 2.Group activity: tongue twister: to learn a new tongue twister and deepen } \\
\text { students' experience of a growth mindset and belief that hardworking can } \\
\text { help them achieve more. } \\
\text { 3.Group activity: a recent bad experience: to learn and practice the optimistic } \\
\text { explanatory style to help students cultivate a rational optimistic attitude } \\
\text { towards the difficulties. } \\
\text { 4.Course review and assignment of practice exercises (Combined with today's } \\
\text { lesson, use the growth mindset and the optimistic explanatory style to } \\
\text { promote daily goal achievement and keep a record of goal completion) }\end{array}$ \\
\hline
\end{tabular}

\subsubsection{Cultivating positive meaning (2 lessons)}

To cultivate positive meaning, on the one hand, guide students to think about the undesirable consequences of lack of meaning, and be more aware of the importance of exploring meaning in life. On the other hand, guide students to discover personal core values and life goals, they can clarify their unique meaning in life.

Table 6: Outlines the information about positive meaning

\begin{tabular}{|c|c|c|}
\hline Module & Subject & Content \\
\hline \multirow[t]{2}{*}{$\begin{array}{l}\text { Positive } \\
\text { meaning }\end{array}$} & $\begin{array}{l}\text { cultivate } \\
\text { gratitude }\end{array}$ & $\begin{array}{l}\text { 1.Review after-school exercise and introduce the topic of the meaning of life (guide students } \\
\text { to celebrate their progress related to their 28-day journey of goal plan; Watch the video: leap, } \\
\text { trigger students to think about the meaning of life) } \\
\text { 2.Group activity: how long will you live (To guide students to realize the shortness of life and } \\
\text { begin to find their purpose in life) and Watch the TED: how to know your life purpose in } 5 \\
\text { minutes? (Use five questions to help you find your purpose in life: Who are you? What are } \\
\text { you doing? Who are you doing it for? What do they need? What transformation will they } \\
\text { achieve in the end?) } \\
\text { 3.Group activity: the gratitude visit exercise (To connect gratefully with others and understand the } \\
\text { meaning of life) and Watch the video: What teens are thankful for (introduce three teenagers read } \\
\text { their letters of gratitude to people they want to thank, like teachers, parents, or friends.) } \\
\text { 4.Course summary and assignment of after-class exercises: (1) Finish your gratitude visit } \\
\text { exercise. Express gratitude to someone through WeChat, phone calls, emails, or meetings, write } \\
\text { down the process and feelings in } 200 \text { words;(2) Watch the video again: how to know your life } \\
\text { purpose in } 5 \text { minutes? Think about the five questions in turn. Write down your answers, and } \\
\text { discover your life purpose and write down in 20o words. }\end{array}$ \\
\hline & $\begin{array}{l}\text { Values and } \\
\text { life } \\
\text { Purposes }\end{array}$ & $\begin{array}{l}\text { 1. Review after-school exercise and introduce the topic of values (To check students' } \\
\text { homework completion, stimulate their positive emotions, and explore the significance of } \\
\text { values) and Watch the video: Wellbeing for children: identity and values (understanding the } \\
\text { influences of life values) } \\
\text { 2. Group activity: My values (To guide students to understand their personal values through } \\
\text { emotional exploration) } \\
\text { 3. Group activity: writing your own eulogy (To guide students to write their own eulogy from } \\
\text { an outsider perspective and explore their purpose in life) } \\
\text { 4.Course summary and assignment of after-class exercises ((1) Look for something that triggers } \\
\text { goosebumps. It must be something stronger and greater than yourself. Appreciate it. It can be } \\
\text { the universe, a star, a mountain, a sea, a river, a great man, or time. Write down your feelings } \\
\text { and experiences in 2oo words; (2) Tell about a bad experience from your past in a new way, } \\
\text { break through the inertia of thinking, and integrate your new feelings and thoughts into the } \\
\text { original viewpoint. Write down your thinking process and feelings in } 200 \text { words). }\end{array}$ \\
\hline
\end{tabular}

\section{Conclusion}

This current study attempted to develop a positive education program that adopted China's " $6+2$ " positive education model to mitigate or prevent academic boredom and increase intrinsic motivation, 
positive emotions, and thought-action repertoires among Chinese college students, which has pioneering significance in mainland China. Based on the existing studies, the researcher creatively integrated the control-value theory of academic emotions and the basic psychological needs theory into the broad-and-build theory of positive emotions and finally formed a theoretical basis for this study. That is, positive emotions can reduce negative emotions like academic boredom by broadening people's attention and increasing thought-action repertoires. Further, it can help students build up more psychological resources that can better calm negative emotions while at the same time satisfying their three basic psychological needs by using a broad range of positive class activities and afterschool exercises. Moreover, positive emotions facilitate students' intrinsic motivation. Although the suggested positive education model has a sound theoretical foundation, empirical evidence is needed to further evaluate its effectiveness before they are used in practice. The researcher just completed the guidelines for the positive education approach which includes a theoretical basis and specific curriculum plans. Later, the researcher will develop an experimental design to investigate the effectiveness of these guidelines on academic boredom and well-being among Chinese college students.

\section{References}

Adler, A. (2016). Teaching well-being increases academic performance: Evidence from Bhutan, Mexico, and Peru (Doctoral dissertation). Available from ProQuest Dissertations and Theses database.Ph.D. thesis. (UMI No. 10190088)

Alan Carr, Katie Cullen, Cora Keeney, Ciaran Canning, Olwyn Mooney, Ellen Chinseallaigh \& Annie O’Dowd. (2020). Effectiveness of positive psychology interventions: a systematic review and meta-analysis. The Journal of Positive Psychology. doi: 10.1080/17439760.2020.1818807

Antonietta Corvinelli MA, OTR (2005) Alleviating boredom in adult males recovering from substance use disorder. Occupational Therapy in Mental Health, 21:2, 1-11. doi: 10.1300/Joo4V21no2_01

Bolier, L., Haverman, M., Westerhof, G.J. et al. Positive psychology interventions: A meta-analysis of randomized controlled studies. (2013). BMC Public Health 13, 119. doi:10.1186/1471-2458-13-119

Dweck, C. S. (2006). Mindset: The new psychology of success. New York: Random House.

Estrada, C. A., Isen, A. M., \& Young, M. J. (1994). Positive affect improves creative problem solving and influences reported source of practice satisfaction in physicians. Motivation and Emotion, 18(4), 285-299. doi:10.1007/BFo2856470

Feng Mengqian. (2017). A study on the relationship between boredom, self-identify and coping style as well as its intervention in high school students. Master Thesis, 55 .

Frank Martela \& Michael F. Steger (2016) The three meanings of meaning in life: Distinguishing coherence, purpose, and significance. The Journal of Positive Psychology, 11:5, 531-545. doi: 10.1080/17439760.2015.1137623

Fredrickson B. L. (1998). What good are positive emotions?. Review of general psychology, 2(3), 300-319. doi:10.1037/1089-2680.2.3.300

Fredrickson, B. L. (2000). Cultivating positive emotions to optimize health and well-being. Prevention $\mathcal{E}$ Treatment, 3(1), Article 1. doi:10.1037/1522-3736.3.1.31a

Fredrickson, B. L., Mancuso, R. A., Branigan, C., \& Tugade, M. M. (200o). The Undoing Effect of Positive Emotions. Motivation and emotion, 24(4), 237-258. doi:10.1023/a:1010796329158

Fredrickson B. L. (2001). The role of positive emotions in positive psychology. The broaden-and-build theory of positive emotions. The American psychologist, 56(3), 218-226. doi:10.1037//0003-066x.56.3.218

Fredrickson, B. L., \& Branigan, C. (2005). Positive emotions broaden the scope of attention and thought-action repertoires. Cognition \& emotion, 19(3), 313-332. doi:10.1080/02699930441000238

Gable, S. L., \& Reis, H. T. (2010). Good news! Capitalizing on positive events in an interpersonal context. In M. P. Zanna (Ed.), Advances in experimental social psychology, 42, pp. 195-257. Academic Press. doi:10.1016/Soo652601(10) 42004-3

Global Council for Happiness and Wellbeing (2019). Global Happiness and Wellbeing Policy Report 2019. (New York: Sustainable Development Solutions Network). http://www.happinesscouncil.org/

Hassed C. (2005). The ESSENCE of health care. Australian family physician, 34(11), 957-960.

Hendriks, T., Schotanus-Dijkstra, M., Hassankhan, A. et al. (2020). The Efficacy of Multi-component Positive Psychology Interventions: A Systematic Review and Meta-analysis of Randomized Controlled Trials. J Happiness Stud 21, 357-39o. doi:10.1007/s10902-019-00082-1 
Hui M., Lin L., Shi S. (2010). A Educational Experimentation Study:the Effects of Different Teaching Methods on College Students'Academic Emotion. Psychological Development and Education, 58(4), 384-389. doi:10.16187/j.cnki.issn1oo1-4918.2010.04.018

Ijeoma, O.B., \& Oladipo, A.I. (2019). Efficacy of Systematic Desensitization Therapy on Academic Boredom among Adolescents in Edo State Secondary Schools. Journal of Educational and Social Research, 9, 83 - 89. doi:10.2478/jesr-2019-0016

Isen, A., Daubman, K., \& Nowicki, G.P. (1987). Positive affect facilitates creative problem solving. Journal of personality and social psychology, 52:6, 1122-31. doi:10.1037/0022-3514.52.6.1122

Jie G., Xiao L., Lu M. (2018). The effects of Satir's Model Group Psychology Counseling on Boredom Proneness of College Students. China Journal of Health Psychology, 276-28o.http://www.cnki.net

Kai P. (2019). Positive Education in Action Featured Course Plans Grade 4-6. Bei Jing, Tsinghua University Press

Lawrence A. Beck (1992) Csikszentmihalyi, Mihaly. (1990). Flow: The Psychology of Optimal Experience, Journal of Leisure Research, 24:1, 93-94, doi: 10.1080/00222216.1992.11969876

Mann, S., \& Robinson, A. (2009). Boredom in the lecture theatre: An investigation into the contributors, moderators and outcomes of boredom amongst university students. British Educational Research Journal, 35(2), 243-258. doi:10.1080/01411920802042911

Nett, U. E., Goetz, T., \& Daniels, L. M. (2010). What to do when feeling bored? Students' strategies for coping with boredom. Learning and Individual Differences, 20(6), 626-638. doi:10.1016/j.lindif.2010.09.004

Norrish, J., Williams, P.L., O'Connor, M., \& Robinson, J. (2013). An applied framework for Positive Education. International Journal of Wellbeing, 3(2),147-161.doi: 10.5502/ijw.v3i2.2

Nett, U. E., Goetz, T., \& Daniels, L. M. (2010). What to do when feeling bored? Students' strategies for coping with boredom. Learning and Individual Differences, 2o(6), 626-638. doi:10.1016/j.lindif.2010.09.004

Norrish, J. M., Williams, P., O'Connor, M., \& Robinson, J. (2013). An applied framework for positive education. International Journal of Wellbeing, 3(2), 147-161. doi:10.5502/ijw.v3i2.2

O'Connell, M. E., Boat, T., \& Warner, K. E. (Eds.). (2009). Preventing mental, emotional, and behavioral disorders among young people: Progress and possibilities (Vol.7). The National Academies Press.

Park, N., Peterson, C., \& Seligman, M. E. P. (2004). Strengths of character and well-being. Journal of Social and Clinical Psychology, 23(5), 603-619. doi:10.1521/jscp.23.5.603.50748

Pekrun, Thomas Goetz, Wolfram Titz \& Raymond P. Perry (2002) Academic Emotions in Students' Self-Regulated Learning and Achievement: A Program of Qualitative and Quantitative Research, Educational Psychologist, 37:2, 91-105, doi: 10.1207/S15326985EP3702_4

Pekrun, R. (2006). The Control-Value Theory of Achievement Emotions: Assumptions, Corollaries, and Implications for Educational Research and Practice. Educ Psychol Rev 18, 315-341. doi:10.1007/s10648-oo69029-9

Pekrun, R., Hall, N. C., Goetz, T., \& Perry, R. P. (2014). Boredom and academic achievement: Testing a model of reciprocal causation. Journal of Educational Psychology, 106(3), 696-710. doi:10.1037/aoo360o6

Perry, Raymond P., Chipperfield, Judith G., Hladkyj, Steve, Pekrun, Reinhard and Hamm, Jeremy M.. (2014). Attribution-based treatment interventions in some achievement settings. Advances in Motivation and Achievement. 18, pp. 1 - 35. doi:10.1108/So749-7423201400000180oo

Pekrun, R., Goetz, T., Daniels, L. M., Stupnisky, R. H., \& Perry, R. P. (2010). Boredom in achievement settings: Exploring control-value antecedents and performance outcomes of a neglected emotion. Journal of Educational Psychology, 102(3), 531-549. doi:10.1037/aoo19243

Peterson, C., \& Seligman, M. E. P. (2004). Character strengths and virtues: A handbook and classification. Washington, DC: American Psychological Association; New York: Oxford University Press.

Ren, J., Huang, Z., Luo, J., Wei, G., Ying, X., Ding, Z., Wu, Y., \& Luo, F. (2011). Meditation promotes insightful problem-solving by keeping people in a mindful and alert conscious state. Science China Life Sciences, 54, 961-965. doi:10.1007/s11427-011-4233-3

Ruthig, J. C., Perry, R. P., Hall, N. C., \& Hladkyj, S. (2004). Optimism and attributional retraining: Longitudinal effects on academic achievement, test anxiety, and voluntary course withdrawal in college students. Journal of Applied Social Psychology, 34(4), 709-730. doi:10.1111/j.1559-1816.2004.tbo2566.x

Ryan, R. M., \& Deci, E. L. (20oo). Self-determination theory and the facilitation of intrinsic motivation, social development, and well-being. American Psychologist, 55(1), 68-78. doi:10.1037/ooo3-066X.55.1.68

Ryan, R. M., \& Deci, E. L. (2002). Overview of self-determination theory: An organismic-dialectical perspective. In E. L. Deci \& R. M. Ryan (Eds.), Handbook of self-determination research (pp. 3-33). University of Rochester Press.

Sharp, J., Hemmings, B., Kay, R., Murphy, B., \& Elliott, S. (2016). Academic boredom among students in higher education: A mixed-methods exploration of characteristics, contributors and consequences. Journal of Further and Higher Education, 41, 657 - 677.doi:10.1080/0309877X.2016.1159292 
Seligman, M., Ernst, R.M., Gillham, J., Reivich, K., \& Linkins, M. (20o9). Positive education: positive psychology and classroom interventions. Oxford Review of Education, 35, 293 - 311. doi: 10.1080/03054980902934563

Seligman, M. E. P. (2011). Flourish: A visionary new understanding of happiness and well-being. New York: Simon \& Schuster

Seligman, M.E.P., Adler, A. (2019). Positive Education. In J.F. Helliwell, R. Layard, \& J. Sachs (Eds.), Global Happiness and Wellbeing Policy Report:2019 (pp.53-72). New York: Sustainable Development Solutions Network

Seldon, A., \& Martin, A. (2017). The Positive and Mindful University. Higher Education Policy Institute, 1-70. Retrieved from www.hepi.ac.uk

Sin, N. L., \& Lyubomirsky, S. (2009). Enhancing well-being and alleviating depressive symptoms with positive psychology interventions: a practice-friendly meta-analysis. Journal of clinical psychology, 65(5), $467-487$. doi:10.1002/jclp.20593

Timothy A. Judge, Amir Erez \& Joyce E. Bono (1998) The Power of Being Positive: The Relation Between Positive Self-Concept and job Performance. Human Performance, 11:2-3, 167-187, doi: 10.1080/o8959285.1998.9668030

Trunnell, E., White, F., Cederquist, J., \& Braza, J. (1996). Optimizing an Outdoor Experience for Experiential Learning by Decreasing Boredom through Mindfulness Training. Journal of Experiential Education, 19, 43 49. doi:10.1177/105382599601900109

Tyler F. Stillman \& Roy F. Baumeister (2009) Uncertainty, Belongingness, and Four Needs for Meaning, Psychological Inquiry, 20:4, 249-251, doi: 10.1080/10478400903333544

Tze, M. C. (2011). Investigating Academic Boredom in Canadian and Chinese Students (Master's thesis). Available from Proquest Dissertations and Theses database.

Tze, V. M. C., Klassen, R. M., \& Daniels, L. M. (2014). Patterns of boredom and its relationship with perceived autonomy support and engagement. Contemporary Educational Psychology, 39(3), $175^{-187 .}$ doi:10.1016/j.cedpsych.2014.05.001

Tze, V. M. C., Klassen, R. M., Daniels, L. M., Li, J. C. H., \& Zhang, X. (2013b). A Cross-Cultural Validation of the Learning-Related Boredom Scale (LRBS) With Canadian and Chinese College Students. Journal of Psychoeducational Assessment, 31(1), 29-40. doi:10.1177/0734282912443670

Tze, V.M.C., Daniels, L.M. \& Klassen, R.M. (2016). Evaluating the Relationship Between Boredom and Academic Outcomes: A Meta-Analysis. Educ Psychol Rev 28, 119-144 doi:10.1007/s10648-015-9301-y

Waters, L. (2011). A review of school-based positive psychology interventions. Australian Educational and Developmental Psychologist, 28(2), 75-90. doi:10.1375/aedp.28.2.75

Westerhof, G. J., \& Keyes, C. L. M. (2010). Mental illness and mental health: The two continua model across the lifespan. Journal of Adult Development, 17(2), 110-119.doi:10.1007/s10804-009-9082-y

Wood, A. M., Linley, P. A., Maltby, J., Kashdan, T. B., \& Hurling, R. (2011). Using personal and psychological strengths leads to increases in well-being over time: A longitudinal study and the development of the strengths use questionnaire. Personality and Individual Differences, 50(1), $15^{-19}$. doi:10.1016/j.paid.2010.08.004

Zeng, G., Zhao, Y. (2019). The Science of Well-being: The Application of Positive Psychology in Education. Bei Jing, Posts \& Telecom Press.

Zhao, Y., Yu, F., Wu, Y., Zeng, G., \& Peng, K. (2019). Positive Education Interventions Prevent Depression in Chinese Adolescents. Frontiers in psychology, 10, 1344. doi:10.3389/fpsyg.2019.01344

Zhao, S., Cai, T. (2012). The Effects of Different Teaching Methods on College Students' Academic Emotion. China Journal of Health Psychology, 20(12), 1900-1902. 